\title{
Late Infiltration of Post-orthodontic White Spot Lesions
}

\section{Spätinfiltration von White-Spot-Läsionen nach kieferorthopädischer Behandlung}

\author{
Klaus W. Neuhaus', Martina Graf ${ }^{2}$, Adrian Lussi', Christos Katsaros²,
}

\begin{abstract}
White spot lesion (WSL) infiltration has been recommended immediately after debonding of orthodontic brackets. It is however not clear if established inactive WSLs can also be masked through infiltration.

Orthodontic treatment of a 19-year-old patient had to be terminated prematurely due to development of multiple WSLs of varying severity. Three months after debonding, the patient presented for lesion infiltration. After etching with $15 \% \mathrm{HCl}$ gel and re-wetting of the dried surfaces it seemed that a good outcome could be expected. Lesion infiltration led to complete masking of less severe WSLs. The visual appearance of moderate and severe WSLs was improved but they were still visible after treatment.

Inactive WSLs may not represent an increased caries risk, but patients are often bothered esthetically. Infiltration by repeated etching might be a viable approach even for inactive WSLs. Controlled clinical trials are needed to investigate the long-term performance of this technique.
\end{abstract}

Key Words: Initial caries - Enamel caries · Orthodontics · Prevention · Penetration · Masking · ICDAS
'Department of Preventive, Restorative and Pediatric Dentistry, School of Dental Medicine, University of Bern, Bern, Switzerland, ${ }^{2}$ Department of Orthodontics and Dentofacial Orthopedics, School of Dental Medicine, University of Bern, Bern, Switzerland.

Received: August 25, 2010; accepted: September 27, 2010

\section{Zusammenfassung}

Die Infiltration initialer kariöser Läsionen (Kreideflecke, WhiteSpot-Läsionen) wird unmittelbar nach der Entfernung kieferorthopädischer Brackets empfohlen. Es ist jedoch unklar, ob auch etablierte Kreideflecken durch Infiltration maskiert werden können.

Bei einem 19-jährigen Patienten musste die festsitzende orthodontische Phase wegen Auftretens multipler initial kariöser Läsionen vorzeitig beendet werden. Drei Monate nach der Entfernung der Brackets wurde der Patient zur Infiltration vorstellig. Nach dem Ätzen mit 15\%igem HCl-Gel konnte durch gezieltes Wiederbefeuchten der getrockneten Zahnoberflächen das zu erwartende Ergebnis antizipiert werden. Die Infiltrationstechnik führte zur vollständigen Maskierung weniger stark ausgeprägter Kreideflecke. Stärker demineralisierte Läsionen wurden optisch verbessert, waren aber nach der Behandlung noch immer sichtbar.

Inaktive Kreideflecke sprechen nicht unbedingt für ein erhöhtes Kariesrisiko, aber Patienten stören sich häufig an der kosmetischen Einbuße. Die Infiltration dieser Läsionen mit multiplen Ätzschritten könnte auch für inaktive Kreideflecke sinnvoll sein. Es fehlen jedoch Langzeitdaten aus klinischen Untersuchungen zur Validierung dieser Methode.

Schlüsselwörter: Initialkaries - Schmelzkaries - Kieferorthopädie - Prävention - Penetration - Maskierung • ICDAS 


\section{Introduction}

The risk of development of white spot lesions (WSLs) during fixed orthodontic treatment is rather high. Several preventive measures have been proposed to minimize the incidence [9]. Generally, the use of fluoride varnish [15] or other fluoride applications [6] has been recommended to avoid white spot lesion formation during fixed appliance treatment. But less is known about how to treat WSLs once they have occurred [7]. It has been shown that some "physiologic" regression of white spot lesions due to enamel remineralization is possible through saliva, although many white spot lesions may remain stable for decades [4]. Chewing gums have been reported to remineralize artificial white spot lesions after 21 days [11]. An enhanced remineralization effect was, however, reported for chewing gums containing caseinphosphopeptide-amorphous calciumphosphate (CPP-ACP) [16]. Clinical studies comparing a fluoridated toothpaste [5] or fluoridated toothpaste plus daily mouth rinse with a CPP-ACP remineralizing cream and $0.05 \%$ fluoridated mouth rinse [1] showed a greater regression of visible WSLs due to the latter. However, this kind of treatment also requires a certain compliance of the patient, as daily application of the cream is required.

Chairside methods have therefore been proposed to treat WSLs instantly regardless of the patient's compliance. One possibility is to micro-abrade the white spot lesions using $\mathrm{HCl}$-erosion followed by polishing with an abrasive pumice $[2,8]$. The white spots are thus abraded and the defects subsequently filled with a resin. This efficacious method, however, sacrifices dental hard substance to an amount of approximately $360 \pm 120$ microns [17]. Another method involving surface erosion with $\mathrm{HCl}$ has been introduced lately [12]. Different from micro-abrasion, the aim of the infiltration technique is not to remove the whitish enamel, but to micro-invasively infiltrate it with a so-called "infiltrant", a polymerizable low viscous resin which fills out the pores of the white spot. It has been shown in vitro that infiltrants have a higher penetration coefficient than regular bonding agents and can thus penetrate the body of incipient carious lesions up to 400 microns [13]. A higher penetration coefficient allows a greater effect of capillary forces, which drives infiltrants deeper into white spots than regular bonding agents.

In the case of post-orthodontic WSLs it has been suggested that infiltration treatment be initiated as soon as possible after bracket removal [14]. White spots tend to be active during and shortly after orthodontic treatment, meaning they tend to progress and thus have a higher risk of loss of surface integrity. Active enamel lesions are micro-porous and feel rough when lightly probed along the surface. Microporosities eventually allow a better lesion infiltration [14]. After removal of the orthodontic appliance, the micro-environment eventually changes and permits white spots to be brushed and cleaned. Under these circumstances, the WSLs change their behavior and become inactive, meaning less

\section{Einleitung}

Das Risiko, White-Spot-Läsionen (WSLs) während einer festsitzenden kieferorthopädischen Behandlung zu entwickeln, ist ziemlich groß. Verschiedene präventive Maßnahmen wurden vorgeschlagen, um ihr Auftreten zu minimieren [9]. Im Allgemeinen wird der Gebrauch von Fluoridlack [15] oder anderen Fluorid-Applikationsformen [6] empfohlen, um eine Entwicklung von WSLs während der aktiven, festsitzenden Phase zu vermeiden. Weniger ist darüber bekannt, wie mit WSLs umzugehen ist, wenn sie einmal aufgetreten sind [7]. Es wurde gezeigt, dass durch den Speichel bis zu einem gewissen Grad eine physiologische Regression von Kreideflecken möglich ist, obwohl viele dieser Läsionen über Jahrzehnte stabil und sichtbar beiben [4]. Ferner wurde berichtet, dass Kaugummis künstliche WSLs in situ nach 21 Tagen remineralisierten [11]. Ein verbesserter Remineralisationseffekt wurde darüber hinaus für Kaugummis berichtet, die Caseinphosphospeptid-amorphes Calciumphosphat (CPP-ACP) enthielten [16]. In klinischen Studien wurde eine größere Regression sichtbarer WSLs nach regelmäßiger Anwendung einer CPP-ACP-haltigen Paste zusammen mit einer $0,05 \%$ igen Fluorid-Mundspülung beobachtet als nach bloßer Benutzung fluoridierter Zahnpasta [5] oder fluoridierter Zahnpasta mit täglicher fluoridierter Mundspülung [1]. Diese Behandlung erfordert jedoch eine gewisse Mitarbeit auf der Patientenseite, da eine tägliche Applikation der Paste nötig ist.

Daher wurden Chairside-Methoden vorgeschlagen, um WSLs sofort und unabhängig von der Mitwirkung des Patienten zu behandeln. Eine Möglichkeit besteht darin, die Kreideflecken mit Mikroabrasion zu behandeln, wobei nach Erosion mit $\mathrm{HCl}$ die Oberfläche mit einer abrasiven Bimssteinpaste poliert wird [2, 8]. Kreideflecken werden so abradiert, und eventuell vorhandene Defekte können dann mit einem fließfähigen Komposit aufgefüllt werden. Diese effiziente Methode opfert jedoch ungefähr $360 \pm 120 \mu \mathrm{m}$ Zahnhartsubstanz [17]. Eine andere Methode, bei der ebenfalls die Zahnoberfläche mit $\mathrm{HCl}$ erodiert wird, wurde kürzlich vorgestellt [12]. Anders als bei der Mikroabrasion besteht das Ziel der Infiltrationsmethode darin, den opaken Schmelz nicht zu entfernen, sondern ihn mikroinvasiv mit einem so genannten Infiltranten zu infiltrieren. Dieses niedrigvisköse Adhäsiv füllt die kariös erweiterten Schmelzporen auf. Es wurde in vitro gezeigt, dass Infiltranten einen höheren Penetrationskoeffizienten haben als reguläre Bondingmaterialien, so dass sie den Körper initialer kariöser Läsionen bis zu $400 \mu \mathrm{m}$ weit durchdringen können [13]. Ein höherer Penetrationskoeffizient ermöglicht den Kapillarkräften einen höheren Wirkungsgrad, so dass Infiltranten tiefer in den Kreidefleck eindringen können als herkömmliche Bondingmaterialien.

Im Fall von WSLs nach Kieferorthopädie wurde vorgeschlagen, die Infiltrationsbehandlung so bald wie möglich nach Entfernung der Brackets zu beginnen [14]. „White Spots" sind eher während und kurz nach der kieferorthopä- 


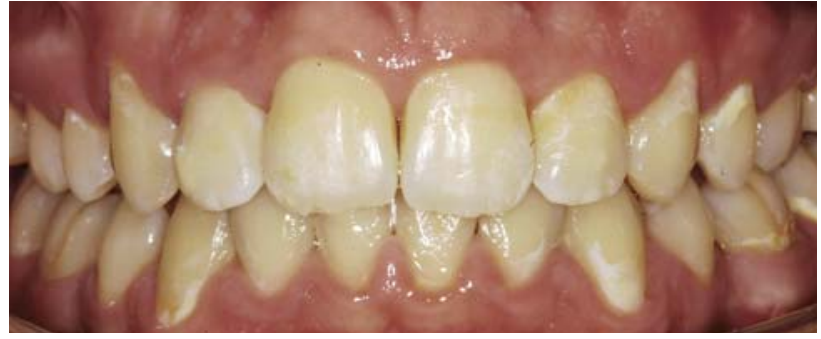

Figure 1. Situation after debonding of the brackets and insertion of a palatal retainer. Upper front teeth are dried out.

Abbildung 1. Situation nach der Entfernung der Brackets und nach Insertion eines palatinalen Retainers. Die oberen Frontzähne sind ausgetrocknet.

likely to progress. An inactive enamel lesion feels smooth on slight probing, and it looks shiny. The histologic correlate is a hardened surface layer of the enamel lesion. Fluoride eventually stabilizes this surface layer but also hampers further remineralization deeper in the body of the lesion [3]. It is not clear and there is not yet histologic proof as to whether inactive WSLs can be successfully treated with the infiltration technique.

\section{Case Report}

This article reports a case of a patient with insufficient compliance leading to multiple WSL formation around fixed orthodontic appliances. The orthodontic treatment had to be terminated before achieving the desired result. The patient was called up for infiltration treatment of his WSLs directly after debonding and prior to insertion of retainers. However, he postponed the treatment and was treated no sooner than 3 months after debonding. The patient gave his informed consent to infiltration treatment and was oriented that the treatment outcome might be not as good as expected.

The patient (healthy male Caucasian) was 18 years old on beginning of the orthodontic treatment and 19 years old on its termination. The teeth showed a molar incisor hypomineralization with opaque hypoplastic spots but no surface discontinuities on the vestibular surfaces of anterior teeth and molar cusps. The patient complained about being severely disturbed by the mottled appearance of his teeth.

Clinical inspection showed WSLs on the labial aspects of teeth $14,13,22,23,24,37,36,34,33,32,42,43,44$, and 47 (Figure 1). All WSLs except for tooth 36 were Code 2 according to the International Caries Detection and Assessment System (ICDAS). Only tooth 36 showed local enamel breakdown (Code 3) requiring restorative treatment. The extent of WSLs however was more pronounced on the canines and premolars than on the front teeth. dischen Behandlung aktiv. Das bedeutet, dass sie zur Progression neigen und ein größeres Kavitationsrisiko aufweisen. Aktive Schmelzläsionen sind mikroporös und fühlen sich rau an, wenn man mit einer spitzen Sonde leicht über die Oberfläche fährt. Mikroporösitäten erlauben eine bessere Infiltration [14]. Nach dem Entfernen der kieferorthopädischen Apparaturen verändert sich jedoch das Mikromilieu, indem die vorhandenen WSLs besser zu reinigen sind. Unter diesen veränderten Umständen verändern sich die Kreideflecken und werden inaktiv, zeigen also weniger die Tendenz zur Progression. Eine inaktive Schmelzläsion fühlt sich bei vorsichtiger Sondierung glatt an und sieht glänzend aus. Das histologische Korrelat ist eine wieder erhärtete Oberflächenschicht des White Spots. Fluorid stabilisiert diese Oberflächenschicht, verhindert aber auch eine weitere Remineralisierung tiefer im Läsionskörper [3]. Es ist noch unklar und der histologische Nachweis darüber fehlt, ob inaktive WSLs erfolgreich mit der Infiltrationstechnik behandelt werden können.

\section{Kasuistik}

Dieser Fallbericht handelt von einem Patienten mit ungenügender Compliance, die zur Entwicklung multipler initialer kariöser Läsionen um die Brackets herum führte. Die kieferorthopädische Behandlung musste daher vor dem Erreichen des angestrebten Ziels abgebrochen werden. Der Patient wurde für eine Infiltrationsbehandlung seiner WSLs nach Debonding und unmittelbar vor der Insertion eines Retainers aufgerufen. Wegen Terminabsage konnte die Behandlung aber erst 3 Monate nach Debonding stattfinden. Der Patient gab sein Einverständnis zur geplanten Infiltrationsbehandlung und wurde darüber aufgeklärt, dass das Behandlungsergebnis eventuell nicht so gut ausfallen könnte wie erwartet.

Der Patient (männlich, gesund, Kaukasier) war zu Beginn der kieferorthopädischen Behandlung 18 Jahre und am Ende der Behandlung 19 Jahre alt. Die Zähne zeigten eine Molaren-Inzisiven-Hypomineralisation mit opaken hypoplastischen Flecken ohne Oberflächeneinbrüche an den Labialflächen der Frontzähne und der Molarenhöcker. Der Patient beklagte eine starke Einschränkung durch das fleckige und gescheckt aussehende Erscheinungsbild seiner Zähne.

Die klinische Inspektion zeigte WSLs an den Labialflächen der Zähne 14, 13, 22, 23, 24, 37, 36, 34, 33, 32, 42, 43, 44 und 47 (Abbildung 1). Alle WSLs außer Zahn 36 entsprachen Code 2 des International Caries Detection and Assessment System (ICDAS). Nur Zahn 36 zeigte einen lokalen Schmelzeinbruch (Code 3), der eine restaurative Behandlung erforderte. Die Ausdehnung der WSLs war bei Eckzähnen und Prämolaren stärker ausgeprägt als bei den Frontzähnen.

\section{Klinische Vorgehensweise}

Die Behandlung wurde für den Oberkiefer und für den Unterkiefer separat geplant. Während der ersten Behandlung wurden alle WSLs im Oberkiefer infiltriert. Die Zähne wur- 


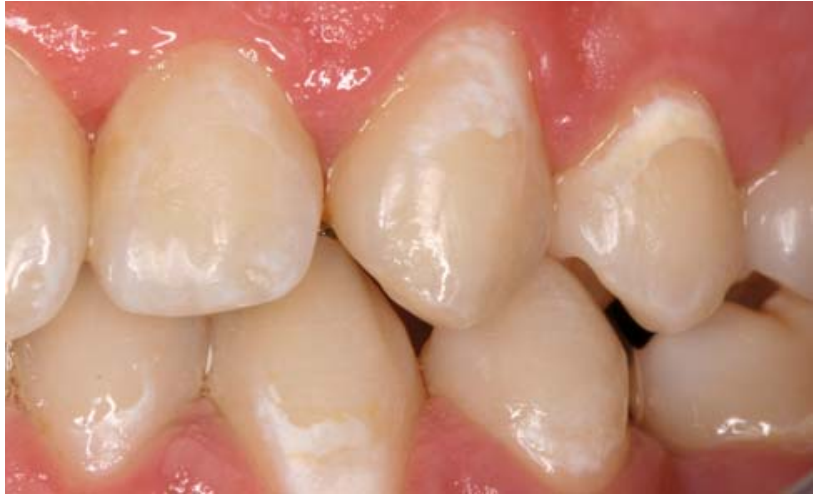

Figure 2. Situation immediately prior to the start of infiltration 3 months after debonding.

Abbildung 2. Situation unmittelbar vor Beginn der Infiltration, 3 Monate nach Debonding.

\section{Clinical Procedure}

The treatment was planned separately for the upper and lower jaws. At the first appointment, the upper WSLs were infiltrated. The teeth were isolated with rubber dam. Due to a palatal retainer from canine to canine, the split dam technique was chosen. After gluing the loose dam to the buccal and palatal gingiva with Histoacryl ${ }^{\circledR}$ (Tissue Seal, Ann Arbor, MI, USA), additional gum isolation with Opaldam ${ }^{\circledR}$ (Ultradent, South Jordan, UT, USA) was applied. The teeth were cleaned first with conventional prophylactic pumice (Cleanic; KerrHawe, Bioggio, Switzerland) (Figure 2 ) and then rinsed and dried. The WSLs were first treated with $15 \%$ HCl-gel (Icon; DMG, Hamburg, Germany) for 2 minutes according to the manufacturer's instructions. After thorough rinsing with air-water-spray for 30 seconds the teeth were dried with compressed air. The appearance of the pretreated labial surfaces was chalky (Figure 3). Rewetting with a moist micro-brush was performed to mimick the anticipated outcome. For persisting visible white spots the etching step was repeated once or twice until a favorable outcome could be mimicked (Figure 4). After applying the drying solution (Icon; DMG, Hamburg, Germany) to the surface, it was conditioned for application of the infiltrant (Icon; DMG, Hamburg, Germany). This infiltrant was applied for 3 minutes and then light cured for 40 seconds. The infiltration was repeated once with application of the infiltrant for 1 minute and subsequent light curing for $40 \mathrm{sec}-$ onds. After infiltration, the surplus was removed using a curette. The tooth surfaces were then polished with a brownie (Shofu, Ratingen, Germany) and with an occlubrush (KerrHawe, Bioggio, Switzerland) using water and light pressure (Figure 5).

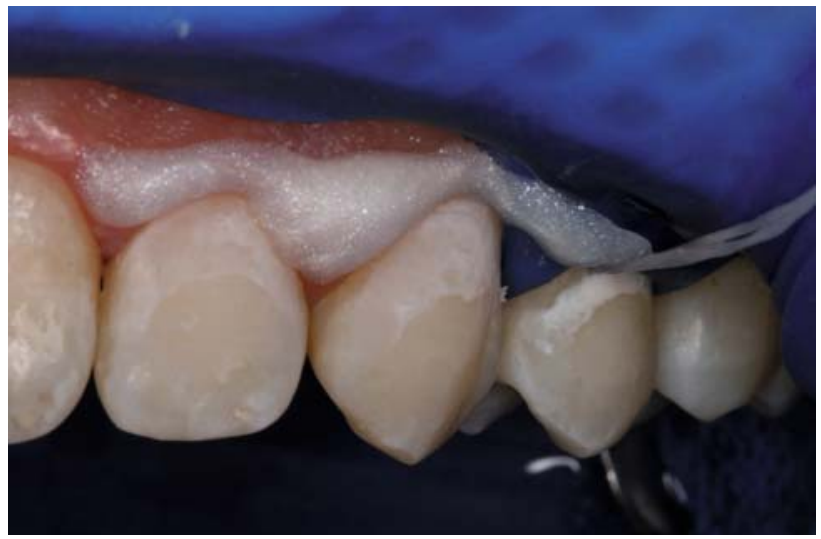

Figure 3. Situation after etching with $15 \% \mathrm{HCl}$-gel. The enamel looks whitish and opaque, but white spot lesions can still be discerned.

Abbildung 3. Nach dem Ätzen mit 15\%igem Salzsäure-Gel. Der Schmelz sieht kreidig opak aus, aber die Kreideflecken setzen sich immer noch farblich ab.

den mit Kofferdam isoliert. Wegen eines Retainers im Oberkiefer von Eckzahn bis Eckzahn wurde die so genannte Split-dam-Technik gewählt. Nachdem der lose Kofferdam am Gaumen mit Histoacryl ${ }^{\circledR}$ (Tissue Seal, Ann Arbor, MI, USA) angeklebt wurde, erfolgte eine Isolation der noch frei liegenden Gingiva mit Opaldam ${ }^{\circledR}$ (Ultradent, South Jordan, UT, USA). Zunächst wurden die Zähne mit einer konventionellen Prophylaxepaste gereinigt (Cleanic; KerrHawe, Bioggio, Schweiz) (Abbildung 2) und anschließend abgesprüht und getrocknet. Die WSLs wurden zunächst mit $15 \%$ igem HCl-Gel (Icon; DMG, Hamburg, Deutschland) entsprechend den Herstellerangaben für 2 Minuten geätzt. Nach gründlichem Absprühen für 30 Sekunden mittels Dreiwegspritze wurden die behandelten Zahnoberflächen mit Druckluft „übertrocknet“. Das Erscheinungsbild der so vorbehandelten Labialflächen war kreidig weiß (Abbildung 3). Ein Rewetting mit einer feuchten Microbrush erlaubte eine Antizipation des zu erwartenden Behandlungsergebnisses. Bei persistierenden Kreideflecken wurde der Ätzschritt ein- bis zweimal wiederholt, bis das gewünschte Behandlungsziel imitiert werden konnte (Abbildung 4). Die Applikation der Trocknungslösung (Icon; DMG, Hamburg, Deutschland) konditionierte die Zahnoberfläche für die eigentliche Infiltration mit dem Infiltranten (Icon; DMG, Hamburg, Deutschland). Dieser wurde für 3 Minuten appliziert und danach 40 Sekunden lichtgehärtet. Der Infiltrationsschritt wurde danach einmal wiederholt, wobei der Infiltrant beim zweiten Mal vor dem Lichthärten (40 s) nur 1 Minute lang appliziert wurde. Nach der Infiltration wurden die Überschüsse mit einer Kürette entfernt. Die Vestibulärflächen wurden anschließend mit einem Brownie (Shofu, Ratingen, Deutschland) und einer Occlubrush (KerrHawe, Bioggio, Schweiz) 


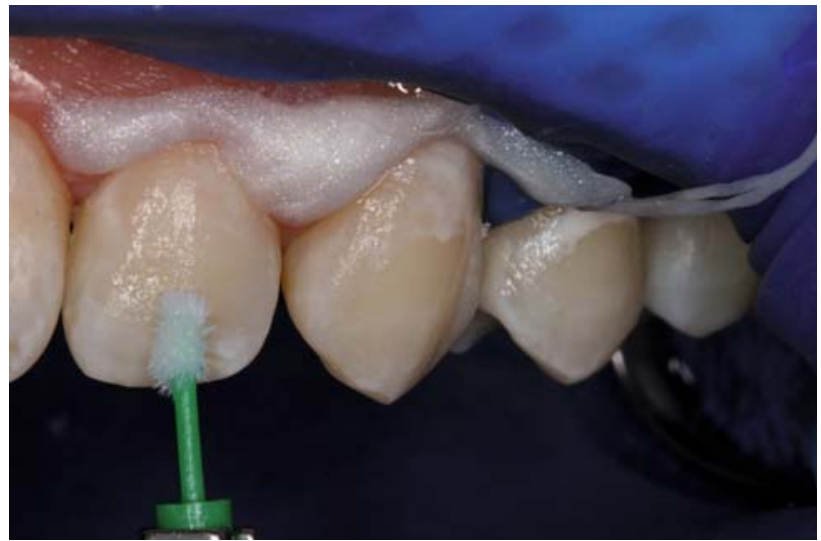

Figure 4. Rewetting with a moist micro-brush mimicks the expected outcome.

Abbildung 4. Das Wiederbefeuchten (Rewetting) mit einer feuchten Microbrush antizipiert das zu erwartende Ergebnis.

In the lower jaw, this treatment was applied accordingly. Tooth 36 received an adhesive class V filling (Ceram X mono; Dentsply, Konstanz, Germany) due to cavitation of the surface.

\section{Discussion}

Pronounced enamel lesions can be expected to have a deeper lesion body. Different lesion depths of WSLs can be expected after debonding. It was therefore interesting to compare the results of the same treatment in WSLs of different severities. A general esthetic improvement could be observed in all WSLs. However, very severe lesions could not be completely masked indicating that the body of the lesion was not completely filled by the infiltrant. The less severe WSLs however became completely invisible or only visible after drying. Thus, in mild to moderate WSLs a shift from ICDAS II score 2 to 1 (lesion only visible after drying for 3-5 seconds with compressed air) or 0 could be achieved in this patient. It has to be noted that the infiltration of WSLs is likely to change its state of activity. In vitro, infiltrated WSLs did not progress, and in vivo infiltration led to a clinically stable situation after 10 months [14]. However, it has to be kept in mind that the method of lesion infiltration has not yet been clinically validated in long-term controlled clinical trials. Moreover, it is noteworthy that etching away the superficial layer of the white spot dissolves the most caries-resistant layer. It was shown that the superficial layer of white spot lesions is significantly more acid-resistant than healthy enamel [10]. Finally, etching of healthy enamel could not be totally avoided. Thus, no statement on the longevity of the treatment, including margin discoloration and development of secondary caries, can be given at the moment. Finally, histology of arrested white spot lesions should be the subject of further research.

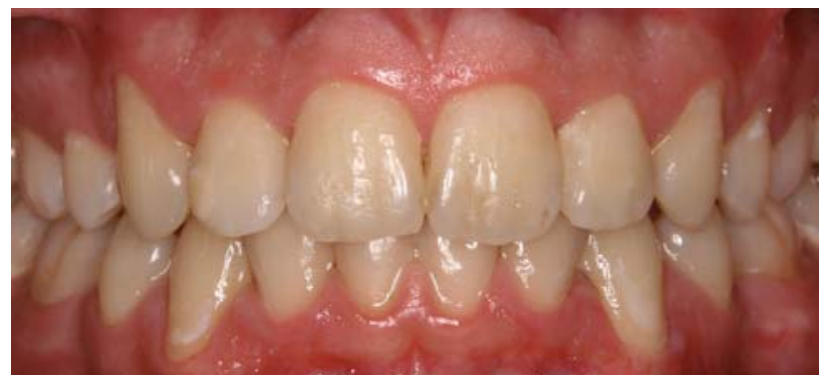

Figure 5. Facial aspect 2 months postoperatively. Generally better appearance, but the severe white spot lesions are still visible.

Abbildung 5. Frontansicht nach 2 Monaten. Das Erscheinungsbild ist generell besser, aber manche Kreideflecken sind immer noch sichtbar.

unter Wasserkühlung mit nur leichtem Druck poliert (Abbildung 5).

Im Unterkiefer wurden die Arbeitsschritte entsprechend wiederholt. Zahn 36 wurde wegen Kavitation der Oberfläche mit einer adhäsiven Klasse-V-Füllung versehen (Ceram X mono; Dentsply, Konstanz, Deutschland).

\section{Diskussion}

Nach Debonding können verschiedene Läsionstiefen von Kreideflecken gefunden werden, wobei deutlich sichtbare WSLs einen größeren Körper der Läsion haben und tiefer sind. Daher war es interessant, das Behandlungsergebnis unterschiedlich stark ausgeprägter WSLs bei gleicher Behandlung zu vergleichen. Eine generelle kosmetische Verbesserung konnte bei allen betroffenen Zähnen erzielt werden. Stark ausgeprägte Kreideflecken konnten jedoch nicht vollständig maskiert werden, was darauf hindeutet, dass der Infiltrant den Läsionskörper nicht vollständig aufgefüllt hat. Weniger stark ausgeprägte WSLs wurden jedoch vollständig maskiert oder waren nur noch nach dem Trocknen sichtbar. Leichte und mittelstark ausgeprägte WSLs konnten bei diesem Patienten also vom ICDAS II Grad 2 zum Grad 1 (Läsion ist sichtbar nach 3-5 Sekunden Trocknen mit Druckluft) oder zum Grad 0 überführt werden. Es kann angenommen werden, dass die Infiltration von WSLs den Aktivitätsstatus der Läsion verändert. In vitro waren infiltrierte WSLs nicht progredient, und in vivo konnte eine klinisch stabile Situation nach 10 Monaten erzielt werden [14]. Man muss jedoch beachten, dass die Publikation von Langzeitergebnissen aus kontrollierten klinischen Studien mit Infiltration von WSLs erst in näherer Zukunft erwartet werden kann. Darüber hinaus muss festgehalten werden, dass durch die Erosion der Oberflächenzone des Kreideflecks die am stärksten kariesresistente Schicht entfernt wird. Es wurde gezeigt, dass die 
However, this case showed that esthetic improvement could be achieved in all WSLs. Interestingly, infiltration worked even when performed "too late" in established, purportedly superficially remineralized WSLs.

\section{Conclusion}

Infiltration might be applicable in post-orthodontic white spot lesions even after conversion to inactive lesions. Repeated etching could be considered as a necessary treatment variation. Controlled clinical trials are needed to test the longevity of the infiltration technique in inactive white spot lesions.

\section{Acknowledgement}

We would like to thank Dr. Sebastian Paris, Kiel, for valuable discussions.

\section{References}

1. Andersson A, Skold-Larsson K, Hallgren A, et al. Effect of a dental cream containing amorphous cream phosphate complexes on white spot lesion regression assessed by laser fluorescence. Oral Health Prev Dent 2007;5:229-33.

2. Ardu S, Castioni NV, Benbachir N, Krejci I. Minimally invasive treatment of white spot enamel lesions. Quintessence Int 2007;38: 633-6.

3. Arnold WH, Cerman M, Neuhaus K, Gaengler P. Volumetric assessment and quantitative element analysis of the effect of fluoridated milk on enamel demineralization. Arch Oral Biol 2003;48:467-73.

4. Backer Dirks 0. Posteruptive changes in dental enamel. J Dent Res 1966;45:503-11.

5. Bailey DL, Adams GG, Tsao CE, et al. Regression of post-orthodontic lesions by a remineralizing cream. J Dent Res 2009;88:1148-53.

6. Benson PE, Parkin N, Millett DT, et al. Fluorides for the prevention of white spots on teeth during fixed brace treatment. Cochrane Database Syst Rev 2004:CD003809.

7. Bergstrand F, Twetman S. Evidence for the efficacy of various methods of treating white-spot lesions after debonding of fixed orthodontic appliances. J Clin Orthod 2003;37:19-21.

8. Croll TP, Cavanaugh RR. Hydrochloric acid-pumice enamel surface abrasion for color modification: results after six months. Quintessence Int 1986;17:335-41.

9. Derks A, Katsaros C, Frencken JE, et al. Caries-inhibiting effect of preventive measures during orthodontic treatment with fixed appliances. A systematic review. Caries Res 2004;38:413-20.

10. Iijima Y, Takagi 0 . In situ acid resistance of in vivo formed white spot lesions. Caries Res 2000;34:388-94.

11. Leach SA, Lee GT, Edgar WM. Remineralization of artificial carieslike lesions in human enamel in situ by chewing sorbitol gum. J Dent Res 1989;68:1064-8.

12. Paris S, Meyer-Lueckel H, Kielbassa AM. Resin infiltration of natural caries lesions. J Dent Res 2007;86:662-6.

13. Paris S, Meyer-Lueckel H, Colfen H, Kielbassa AM. Penetration coefficients of commercially available and experimental composites intended to infiltrate enamel carious lesions. Dent Mater 2007;23:742-8.

14. Paris S, Meyer-Lueckel $H$. Masking of labial enamel white spot lesions by resin infiltration - a clinical report. Quintessence Int $2009 ; 40: 713-8$
Oberflächenzone eines Kreideflecks signifikant säureresistenter ist als gesunder Schmelz [10]. Es konnte außerdem nicht vollständig verhindert werden, dass auch gesunde Schmelzareale mit Salzsäure angeätzt wurden. Insofern muss man festhalten, dass zum jetzigen Zeitpunkt der Langzeiterfolg der Behandlung, einschließlich des Risikos der marginalen Randverfärbung oder des Auftretens von Sekundärkaries, nicht sicher ist. Abschließend sei angemerkt, dass histologische Untersuchungen inaktiver White-Spot-Läsionen Gegenstand weiterer Forschung sein sollten.

Dieser Fall zeigte, dass eine kosmetische Verbesserung bei allen WSLs erreicht werden konnte. Interessanterweise funktionierte die Infiltration sogar bei „zu später“ Durchführung bei inaktiven, vermutlich oberflächlich remineralisierten WSLs.

\section{Schlussfolgerung}

Die Infiltration kann bei nach kieferorthopädischer Behandlung aufgetretenen Kreideflecken Anwendung finden, auch wenn diese schon arretiert sind. Wiederholte Ätzschritte können bei ausgeprägten Läsionen als Behandlungsvariante ins Auge gefasst werden. Kontrollierte klinische Studien sind notwendig, um den Langzeiteffekt der Infiltrationstechnik aus kosmetischen Gründen bei inaktiven White-Spot-Läsionen zu validieren.

\section{Danksagung}

Dank gebührt Dr. Sebastian Paris, Kiel, für eine wertvolle Diskussion.

15. Stecksen-Blicks C, Renfors G, Oscarson ND, et al. Caries-preventive effectiveness of a fluoride varnish: a randomized controlled trial in adolescents with fixed orthodontic appliances. Caries Res 2007; 41:455-9.

16. Sudjalim TR, Woods MG, Manton DJ, Reynolds EC. Prevention of demineralization around orthodontic brackets in vitro. Am J Orthod Dentofacial Orthop 2007;131:705 e1-9.

17. Tong LS, Pang MK, Mok NY, et al. The effects of etching, micro-abrasion, and bleaching on surface enamel. J Dent Res 1993;72:67-71.

\section{Correspondence Address}

Dr. Klaus W. Neuhaus

Department of Preventive, Restorative and Pediatric Dentistry

Freiburgstr. 7

3010 Bern

Switzerland

Phone: (+41/31) 6324974

e-mail: klaus.neuhaus@zmk.unibe.ch 